\title{
Research into the Feasibility of Implementing CBI in Vocational and Technical Colleges in Chinese Context
}

\author{
Xu Lei \\ Sichuan Nursing Vocational College \\ No. 199, First Ring Road, Deyang City 618000, China \\ E-mail: 1061959820@qq.com
}

Received: September 3, 2017 Accepted: October 8, 2017 Published: October 10, 2017

doi:10.5296/elr.v3i2.11979 URL: http://doi.org/10.5296/elr.v3i2.11979

\begin{abstract}
In order to explore the feasibility of applying Content-based Instruction (CBI) method in vocational and technical colleges in China, with 4 research questions this study employed a combination of qualitative and quantitative research methods whose instruments included questionnaire survey and interview. The samples of this study were 205 sophomores from 3 different majors, all of whom registered to take "Building and Construction Engineering English" (BCEE) CBI courses. The results demonstrated that the majority of population benefited from $\mathrm{CBI}$ for their learning motivation and interest were greatly increased owing to organic integration of English language learning and major-related subject matters. Furthermore, these subjects became more inclined to be cultivated as "double-qualified" talents who can use English as a communicative tool to solve problems in their lives. This study proves that it is feasible to incorporate English language acquisition into subject content learning through CBI, which could be one of the most effective means of Chinese college English reform and thus be duplicated in other EFL countries where CBI is conducive to fostering competent "double-qualified" graduates from vocational and technical colleges so as to adapt to the trend of globalization and exert positive effects on cultivating internationalized talents all around the world.
\end{abstract}

Keywords: CBI, BCEE, English proficiency, Subject matters, "Double Qualified” talents

\section{Introduction}

In order for students to integrate their College English learning with major-related subject matters relied on which they can earn their bread after graduation, a classroom-based, process-oriented, off-and-online combined CBI course called "Building and Construction Engineering English" (BCEE) is set up in a vocational and technical college in Sichuan Province, whose main aim is to cultivate professional talent workers for building and 
construction engineering fields such as Civil Engineering, Railway Engineering, Electromechanical, Tunnel Construction, Road and Bridge Construction, Transportation and Management etc. Building and Construction Engineering English was first introduced 3 years ago in 2013 and was a main course for Applied English majors (International Engineering Contract) in their curriculum design. This course uses "Building and Construction Engineering English" as the textbook, building construction as its main thread and basis, whose contents involve building material, building craft, project management, interior decoration, exterior engineering, installation engineering, landscaping, site report etc. The teaching objectives are to foster inter-disciplinary and versatile talents in building and construction fields. Combining students' acquired professional knowledge with practical working requirements after graduation, this course strives to provide them with English knowledge and skills related to their posts of duty in the future. It also aims to raise students' abilities in how to use professional English, especially in reading and translation abilities of English literature in building and construction engineering areas, on-site interpretation ability with foreign English speakers and communicative competence. The distinctive feature of this course lies in that it highlights the constructional and developmental orientation and function of this major which is stated as "Cultivate double-qualified graduates who can not only speak English, but also understand engineering". In a sense, "Building and Construction Engineering English" course is an integration of professional building knowledge and English linguistic skills which closely encircles the construction and development of this major. From the perspective of construction management, this course involves preliminary work before construction, control and supervision in construction, maintenance after construction. From technical point of view, this course includes foundation construction, body construction, finishes and exterior engineering in which the complete construction process is presented to students sequentially and thoroughly. On English language level, this course focuses on fostering students communicative and practical using abilities on construction site. In China, building industry is one of the backbones of national economy whose driving-force function in GDP and GNP is becoming more conspicuous. Nowadays, China's "One Belt and One Road" developmental strategy not only brings about hard-won opportunity for development, it also brings along with tough challenges and impacts. In fact, building industry has to face fierce competitions from international contractors, so in order to have a share and stand steady in international engineering and contraction market, improving Chinese native talents' qualities and competences is of first priority. Under such backgrounds, to design and develop "Building and Construction Engineering English" course can not only solve long-standing problems and a state of embarrassment in engineering concerning foreign affairs in building industry, i.e. he who can speak English does not know engineering, he who knows engineering cannot speak English, it can also elevate students' core employment competitiveness after graduation in which their major's characteristics will stand out. As a consequence, this course gives strong supports to the development and orientation of building and construction engineering major which is indispensible to the construction and acceleration of building industry. The features of design and innovative points of Building and Construction Engineering English lie in: first of all, it increases students' English applying ability in building construction environment and places emphasis on cultivating 
students with communicative competence and building up a foundation for sustainable development. Secondly, cultivation of building and construction knowledge and abilities is so underlined that students can get acquaintance of 1st-line construction activities and master relevant knowledge in building industry. Thirdly, practicality and practicability are used as the principal to organize course curriculum which aims to present students with the entire construction process and highlight the combination of linguistic competence and building knowledge. In addition, textbook structure is arranged reasonably and teaching contents are painstakingly picked up. Every unit encircles a theme to practice both students' linguistic skills and building knowledge, increase their communicative abilities in English in building and construction realm and reading ability in English literature, and enhance their understanding of building knowledge. Last but not least, illustrations related to content are attached in each unit, which is both beneficial to students' understanding of building knowledge and supplies them with practical English language using context.

\section{Literature Review}

By Richards and Rogers' definition (2001), CBI refers to an approach to second language teaching in which teaching is organized around the content or information that students will require, rather than around other type of syllabus. From a pedagogical and academic point of view, Brinton, Snow, and Wesche (1989) claim that CBI is the integration of particular contents with language teaching aims and define CBI as the concurrent study of language and subject matter, with the form and sequence of language presentation dictated by content material. Met (1999) provides "a continuum of content and language integration" that ranges from the most content-driven end, which is total immersion followed by partial immersion to the most language-driven end, which are language classes with frequent use of content and theme-based courses.

Combining the aforementioned definitions from different linguistic and pedagogical experts, Content-based Instruction (CBI) is a language teaching method which uses the target language (in Mainland China, i.e. English) as a tool to teach other subjects in school curriculum, such as Mathematics, Physics, Chemistry, Science, Geography, History, Politics, Music and so on. The language itself is not regarded as a subject matter to learn in the class anymore; instead, it is used as a means of teaching major content-related knowledge that is the focus in the class in place of mother tongue.

\section{Empirical Studies at Home and Abroad}

Since CBI combines language learning with subject content learning and enables students not only to improve linguistic proficiency but also acquire subject knowledge, it is becoming quite popular in language teaching field in recent three decades (Crandall, 1987; Brinton, 1997; Kasper, 2000; Mohan, 1986; Grabe \& Stroller, 1997; Stryker \& Leaver, 1997; Wesche $\&$ Skehan, 2002). Due to the fact that subject content knowledge has an extensive coverage in $\mathrm{CBI}$, a large number of courses and teaching syllabi are therefore been developed. These subject matters in CBI include Literature (Holten, 1997), History (Srole, 1997), Movies (Chapple \& Curtis, 2000), Country and District Issues (Stryker \& Leaver, 1997) etc. There also exist reports and records of CBI regarding Psychology, Economics, Geography and Politics (Dupuy, 2000). CBI can be regarded as one of the most representative contributions to modern ESL/EFL field and the following part will discuss CBI research in different 
language teaching circumstances and contexts in China and overseas.

\section{1). CBI Research in ESL Context}

A large quantity of literature indicates that it is beneficial to elevate students' language level when they use the target language to learn other academic courses. This is already proved by some CBI trials, especially in ESL context. In Sheltered Subject-matter Instruction and Adjunct Course, this way of teaching on basis of other subjects has proven to be effective and efficient to improve students' academic performances and their SL proficiency (Wesche, 1993; Grabe \& Stroller, 1997; Snow \& Brinton, 1997; Stryker \& Leaver, 1997). Studies in Ottawa University demonstrate that In CBI courses, students learning effectiveness and efficiency via using SL to learn subject matters are no worse than those who use their native L1 to learn the same subjects. In addition, not only do students in CBI classes have an obvious development in their language proficiency, but also they can build up confidence of expressing their ideas in SL by the benefit of CBI (Edwards et al., 1984). Moreover, an evaluation study in 7 different Adjunct Courses indicates that all of the students who engage in Adjunct Course learning have acquired a higher level of linguistic proficiency (Wesche, 1993). Burger and Chretien (2001) carry out an investigation of CBI's effect on students' oral proficiency in Ottawa University. The survey result illustrates that students engaging in Adjunct Course have greatly improved oral proficiency no matter in terms of fluency or accuracy. It is found in Kasper' research (1994) that students attending CBI ESL courses tend to get a higher grade than those attending non-CBI ESL courses in reading tests and find it easier to pass ESL course assessment.

\section{2). CBI Research in EFL Context}

Chumpavan (2001) carries on a CBI empirical study in EFL context in Thailand, the result implies that compared with normal language teaching, CBI teaching method is more contributive to Thai college undergraduates' English language learning. In Puerto Rico, Torres (2000) investigates 2 different models that can promote English speaking proficiency for Grade 10 students, i.e. Immersed Bilingual Teaching Model and Traditional Language Teaching Model. In Taiwan, CBI is usually integrated in Immersion Program or ESP courses (Jan, 2004). Immersion Program is commonly used in pre-school, elementary and junior high school periods; while ESP is widely promoted in vocational, technical and higher education. Due to misunderstandings by some kindergartens' leader and parents and the range of target language learning is limited, Immersion Program is often questioned by the mass. But in some vocational and technical schools, ESP courses attain a wide range of applause (Chen, 1998). Huang (2003) writes that Content-based EAP courses apply real-life news from English newspapers, magazines and Internet into Content-based EAP course "International Communicative English" which is opened specifically to postgraduates who are engaging in international studies. According to Huang, students' reaction to this course is very positive. However, since specialty subject knowledge is limited and it meets difficulty in providing Adjunct Courses, nearly all ESP courses in Taiwan are taken over by subject teachers (Hsu, 2000). In Hong Kong, CBI has different models and each model has distinctive teaching outcome which results in both positive and negative consequences. It is reported that Theme-based CBI model is not successful in Hong Kong (Gu \& Dong, 2005). Nevertheless, there is a report that EGP courses in the Chinese University of Hong Kong successfully apply 
movie contents into CBI teaching (Chapple \& Curtis, 2000). In mainland China, in spite of the fact that CBI's effect is significant in various kinds of educational institutes, yet there are only a few empirical studies on CBI up to now. Immersion Program has a wide coverage in kindergartens, elementary and secondary schools such as report about a successful case study in Shanghai (Zhu, 2003). Liu and Cai (1997) conduct an immersion teaching experiment in Guangdong University of Foreign Studies which indicates that after one semester's experiment, although there is no significant difference between students engaging in Immersion Program and those in traditional language teaching courses in terms of overall linguistic proficiency, yet in terms of productive skills, i.e. speaking and writing abilities, the experimental group is significantly better than the control group. In the meantime, in terms of receptive skills, i.e. listening and reading, two groups are almost equal with each other. Apart from dabbling in subject matters, students in experimental group are much more inclined to raise interest and pose a positive attitude in English and its related cultural learning. Xu's empirical study of CBI (2006) indicates that CBI has effectively increased English learning abilities of Chinese majors in Tai Zhou Normal University. Xing (2006) in Content-based Extensive Reading courses proves that students attending Content-based Extensive Reading courses have a much more noticed improvement than those in normal reading classes. It is noteworthy that even though great successes have been achieved in CBI empirical studies on English majors in Dalian University of Foreign Languages (Chang, 2015) and non-English majors in a comprehensive university in China (Yuan, 2014), there is still a big research vacuum in vocational and technical colleges where students have much more vocational needs and are more motivated to learn CBI related to their professional skills and future career. These students seem to have a stronger desire and are more clearly profession-oriented to learn CBI courses than those from EGP universities. Therefore, CBI model in Chinese vocational and technical college English teaching context requires a deeper and more profound study.

\section{Research Design}

In this study, 4 research questions were explored as following:

Research Question 1: What attitudes and perceptions do vocational and technical college students hold toward CBI?

Research Question 2: What are the advantages of carrying out CBI in vocational and technical colleges?

Research Question 3: What are the current problems of carrying out CBI in vocational and technical colleges?

Research Question 4: What qualifications should college English teachers have when they are carrying out $\mathrm{CBI}$ ?

\section{Subjects of the Study}

Students taking part in this experimental research are all sophomore undergraduates in a vocational and technical college in Sichuan Province, coming from 3 different majors including Tunnel Construction (53 students), Traffic Running \& Administrative Management (69 students) and Road \& Bridge Construction (83 students). In total, the sample capacity was 205 students in which male students occupied the majority of the sample (only 1 female 
in Tunnel Construction class) for gender characteristics and features in Building and Construction colleges. All of the subjects were undifferentiatedly classified in the classes after 1 year's General College English instruction during which 3 different level classes (A, B, C) were stratified among students who had diversified English foundations (A: the Highest level; B. the Medium Level; C: the Lowest Level based on their College Entrance Examination scores).

\section{Instrumentation}

So as to assess effects of CBI in Chinese vocational and technical college context, Questionnaire Survey and Recorded Interview were mainly used as research instruments by the researcher. The instrumentation has been widely used in Social Science research in China and abroad, and the validity and credibility of instrumentation have proved to be very high in the experiment. All of the subjects completed the Questionnaire Survey after which data were collected by the researcher as the quantitative research source to conduct SPSS analysis. 4 teachers (3 Chinese including 1 professor, 1 associate professor and 1 new recruit; 1 foreign teacher) and 9 students from different majors accepted the qualitative research Recorded Interview.

\section{Procedures of Data Collection}

\subsection{Questionnaire Survey}

In order to survey students' attitudes to, perceptions and understandings of BCEE course in the vocational and technical college in Sichuan Province, the researcher designed a 5-point Likert-scale based (1 point: Strongly Disapprove, 3 point: Medium, 5 point: Strongly Approve) Questionnaire Survey of 12 questions in which supplemented with 6 "A, B, C, D, E" multiple choice questions. The Questionnaire Survey was filled in by all of 3 major classes in the middle of the semester when they had adequate input and experience of CBI in BCEE course and study burden of final examination and burnout of learning this course did not appear. For the purpose of increasing Questionnaire Survey's reliability, the researcher took advantage of classroom time to ask students to finish the Questionnaire Survey and informed students to read questions carefully before writing down the answers in which mediocre and ambiguous answers such as choosing " 3 " in Likert-scaled questions and "I don't know" in multiple choices questions should be avoided as much as possible. All of the questions and specifications were written in Chinese so that all of the students could complete the Questionnaire Survey without misunderstanding. Meanwhile, researcher offered detailed explanations to erase students' anxiety and misgiving of this survey and motivated them to express their ideas and opinions according to their will and actual feeling before filling in the Questionnaire Survey for the benefit of adjusting and improving CBI teaching efficiency in this course. In the process of filling in the Questionnaire Survey, the researcher gave students necessary instructions and answered their put-up questions in time to ensure everyone could express their genuine ideas and accurate opinions of this course. To avoid mutual influence, students were instructed to complete the Questionnaire Survey independently without any discussion or cooperation. Due to uncontrollable factors such as students' sick leave, absence from class and invalid questionnaire, 193 out of 205 handouts (94.15\%) were collected in valid for further statistical analysis and study. After the Questionnaire Survey was collected, data were typed into computer for further statistical treatment and analysis conducted by 


\section{Macrothink}

SPSS 17.0 software. One-ANOVA was used to compare the differences in attitudes and perceptions to CBI among 3 different major students in the vocational and technical college in Sichuan Province. Qualitative analysis was then used to assess students' understanding, feeling and suggestion of CBI in classroom instruction.

\subsection{Interview}

Semi-Structure interview was used in this study to elicit teachers' and students' understandings, attitudes, perceptions and suggestions of CBI. In order for every interviewee to fully understand interview questions, Chinese language was used in Chinese students' and teachers' interview; while English language was used in the interview with foreign CBI teacher. To compensate with each other, Individual interview with teacher and group interview with students were both used by the researcher to get the authentic information. In order not to interrupt interviewees in the process of interviewing by interviewer's taking notes and analyze the interview with careful thoughts after the instant interview, smart-phone audio recorder was used to record the conversation and written transcription was made by the researcher later after listening to the recordings several times.

\section{Results and Discussions}

Before conducting Factor Analysis of the Questionnaire, SPSS 17.0 was used to test the internal consistency in which Cronbach's alpha was more than 0.7 (relatively high internal consistency), which meant the reliability of the Questionnaire was high and the survey result was hence acceptable. Factor Analysis was carried out by SPSS 17.0 henceforth.

In the process of Factor Analysis, the researcher organized the first 12 Likert-scaled questions in the Questionnaire Survey into 4 factors: 1. Students' Emotions \& Attitudes (SEA) including q1, q2, q3. 2. Students' Cognition of CBI (SCO) including q10, q11, q12. 3. Teachers' Teaching \& Assessment Model (TTA) including q4, q5, q6. 4. Students' Real Experience (SRE) including q7, q8, q9. After calculation by SPSS 17.0, the Mean of each factor in 3 different majors was listed in the following table. 
Table 1. Means of Each Factor in 3 Different Majors

A. Tunnel Construction

\begin{tabular}{llll}
\hline & $\mathrm{N}$ & Mean & Std. Deviation \\
\hline SEA & 49 & 3.7551 & .56836 \\
SCO & 49 & 3.8367 & .53195 \\
TTA & 49 & 3.4898 & .64227 \\
SRE & 49 & 3.5238 & .63828 \\
\hline
\end{tabular}

B. Traffic Running \& Administrative Management

\begin{tabular}{llll}
\hline & $\mathrm{N}$ & Mean & Std. Deviation \\
\hline SEA & 61 & 2.9508 & .62312 \\
SCO & 61 & 3.2295 & .76870 \\
TTA & 61 & 3.0109 & .69647 \\
SRE & 61 & 3.1093 & .62870 \\
\hline
\end{tabular}

C. Road \& Bridge Construction

\begin{tabular}{llll}
\hline & $\mathrm{N}$ & Mean & Std. Deviation \\
\hline SEA & 83 & 3.1446 & .67714 \\
SCO & 83 & 3.4137 & .80073 \\
SRE & 83 & 3.0120 & .55202 \\
TTA & 83 & 3.4297 & .71479 \\
\hline
\end{tabular}

From the above 3 tables, we can find out that Means of SCO (Students' Cognition of CBI) account for the highest in all of the 4 factors in nearly all of 3 majors, especially for Tunnel Construction majors: nearly 4 points in average which means that students have got a clear idea of CBI in BCEE course and they are highly motivated and have interest to learn CBI for the benefit of broadening horizons and future career. In the meanwhile, the Std. Deviation of this factor is the highest as well in the other 2 majors (as high as 0.8 or so) which indicates that polarization is formed in CBI BCEE classes maybe because of students' varied English foundations which facilitates good learners to improve their English skills through learning major-related subject matters and burdens poorer learners when they already find it difficult and boring to learn English language before, but now have to study extra content knowledge through specialty English which contains too much complex professional English vocabulary and expressions. Another factor we should pay attention to is TTA (Teachers' Teaching \& Assessment Model) which gets the lowest Means in 4 factors in B and $\mathrm{C}$ majors (only about 3 points in average). This result implies that students haven't changed from the traditional passive knowledge "recipient" role to active knowledge "constructor" role. The majority of 


\section{Macrothink}

them still hold that teacher is the dominator of class-time and knowledge should be instilled from teacher rather than obtaining it by critical thinking, discussion and cooperation. One reason for this maybe in their former learning experiences and in freshman-year college English courses, students have become accustomed to traditional passive learning model and haven't considered the relationship between knowledge acquired in class and its practical application in real-life situations. Another point needed to be pointed out is that although the Means of 4 factors in A major are the highest in all of 3 majors (above 3.5 in average) which indicates that the students in this class have the strongest support and best acceptance of CBI model in BCEE course, yet in the process of classroom instruction, the teacher found that students' English foundation in A major was the weakest in general among 3 majors and passive study habit was the most prominent in this class as well which was presented by unable to express their own ideas or opinions in English and lacking independent creative thinking and interaction with teacher in class. The explanation of this interesting phenomenon maybe that precisely because of relatively weaker English foundation and poorer English academic performance before, students in A major were more highly stimulated and much more eager to accept new English language learning methods such as CBI in BCEE course to change their English learning situation and improve their comprehensive English skills as a result. However, due to the shortage of English vocabulary and lack of confidence to speak in English, they preferred accepting existing knowledge without discrimination in silence to audaciously answering questions and positively constructing their own understanding of the knowledge which might cause others' teasing and thus lose face in front of the class.

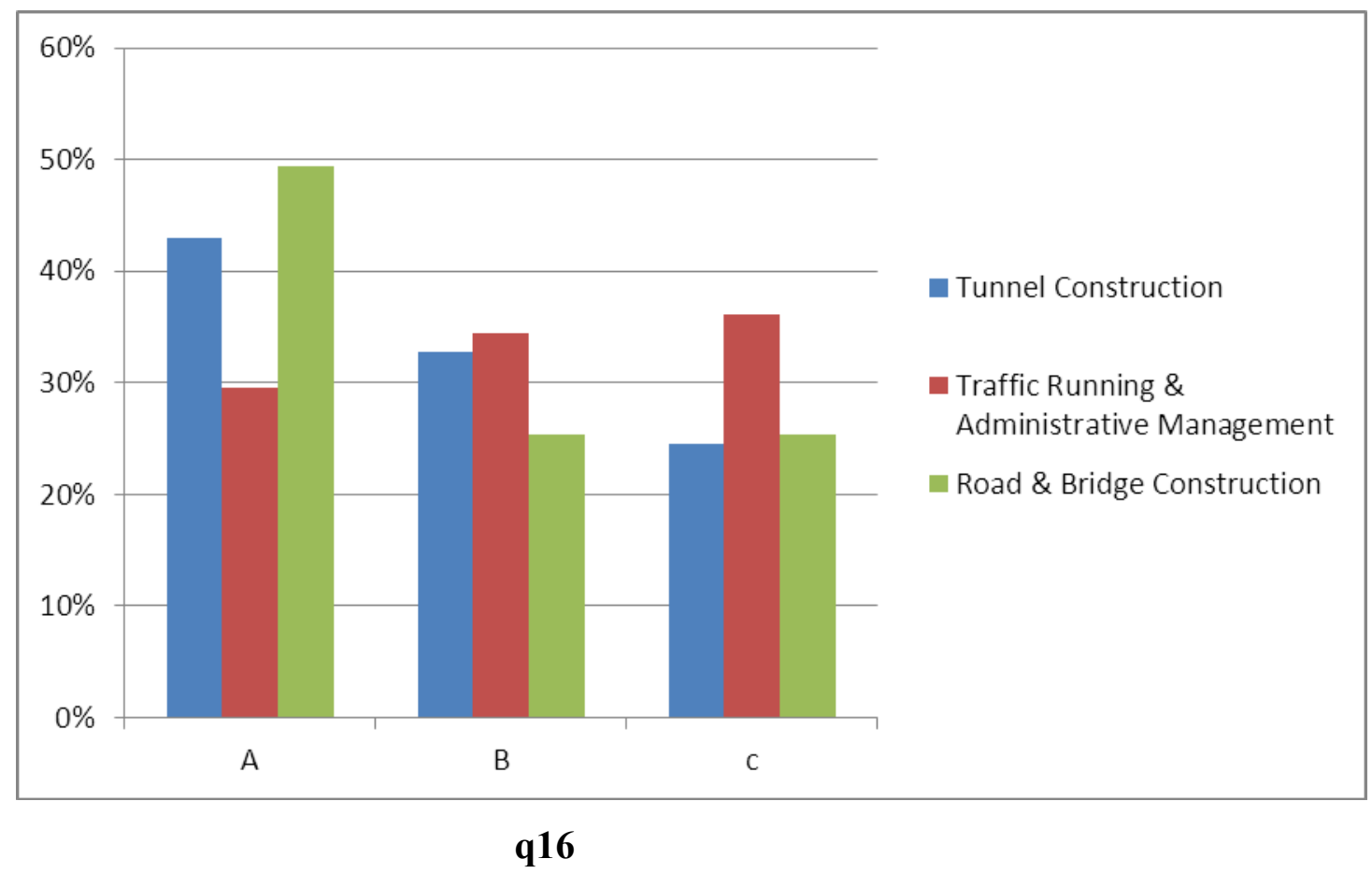
A: Agree
B: I don't know
C: Disagree

Figure 1. Students' Self-Evaluation of Their Competence of Learning BCEE CBI Course 


\section{Macrothink}

In Figure 1, it illustrated the percentage of students' self-evaluation of their competence of learning BCEE CBI course, where marked differences occurred among 3 majors. In Tunnel Construction Major group, about $45 \%$ of students believed that they had the ability to learn this course well whilst in other 2 major groups, the percentage fell to about $30 \%$. By contrast, as much as $50 \%$ of students in Tunnel Construction Major doubted that they were competent enough to learn BCEE CBI course, nearly doubled the percentage in Traffic Running \& Administrative Management Major and Road \& Bridge Construction Major (about 25\% in respective). Moreover, there were quite a few students having no clear idea or assessment about whether they were qualified to learn this course or not (ranging from $30 \%$ to $35 \%$ ).

In the following Figure 2 and Figure 3, we can see all of 3 major students most favored in learning both English language and subject matters together (over 60\%) in BCEE CBI course rather than learning only English or subject matters otherwise. By comparison, only a very small group of students in 3 majors (from 10\% to 25\%) preferred either learning English language or gaining content knowledge as the focus in BCEE CBI course. Meanwhile, we need to notice that students' willingness to acquire both English linguistic knowledge and subject content knowledge in this course decreased slightly with their better English foundations and more enriched professional building \& construction knowledge (Tunnel Construction Major with the highest willingness at about 70\%; Traffic Running \& Administrative Management Major in the middle at around 65\%; Road \& Bridge Construction Major with the lowest at $60 \%$ or so).

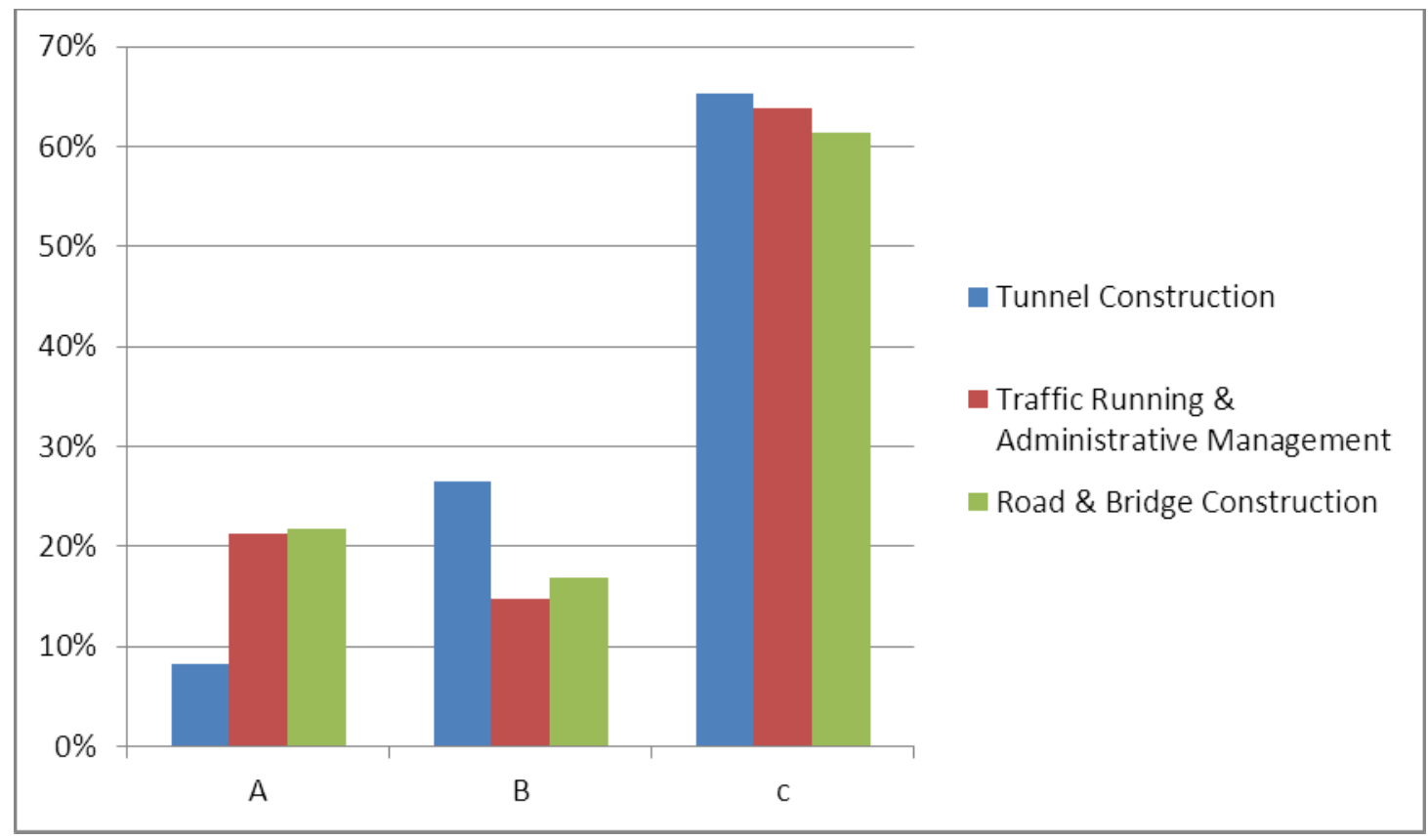

q18
A. English Linguistic Knowledge
B. Subject Matters
C. Both

Figure 2. Teacher's Teaching Focus in BCEE CBI Course 


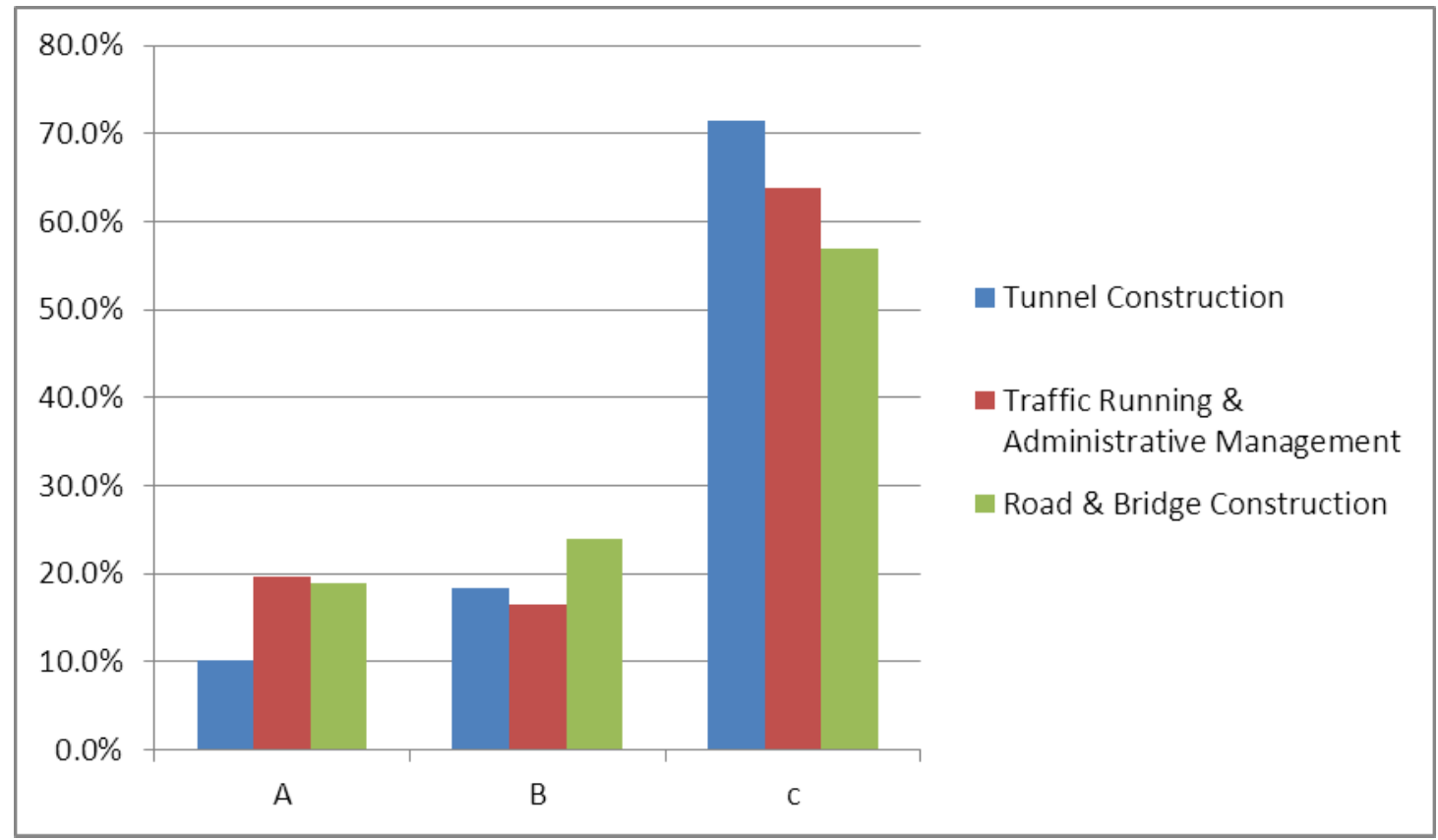

q19
A. English Linguistic Knowledge
B. Subject Matters
C. Both

Figure 3. Students' Learning Focus in BCEE CBI Course

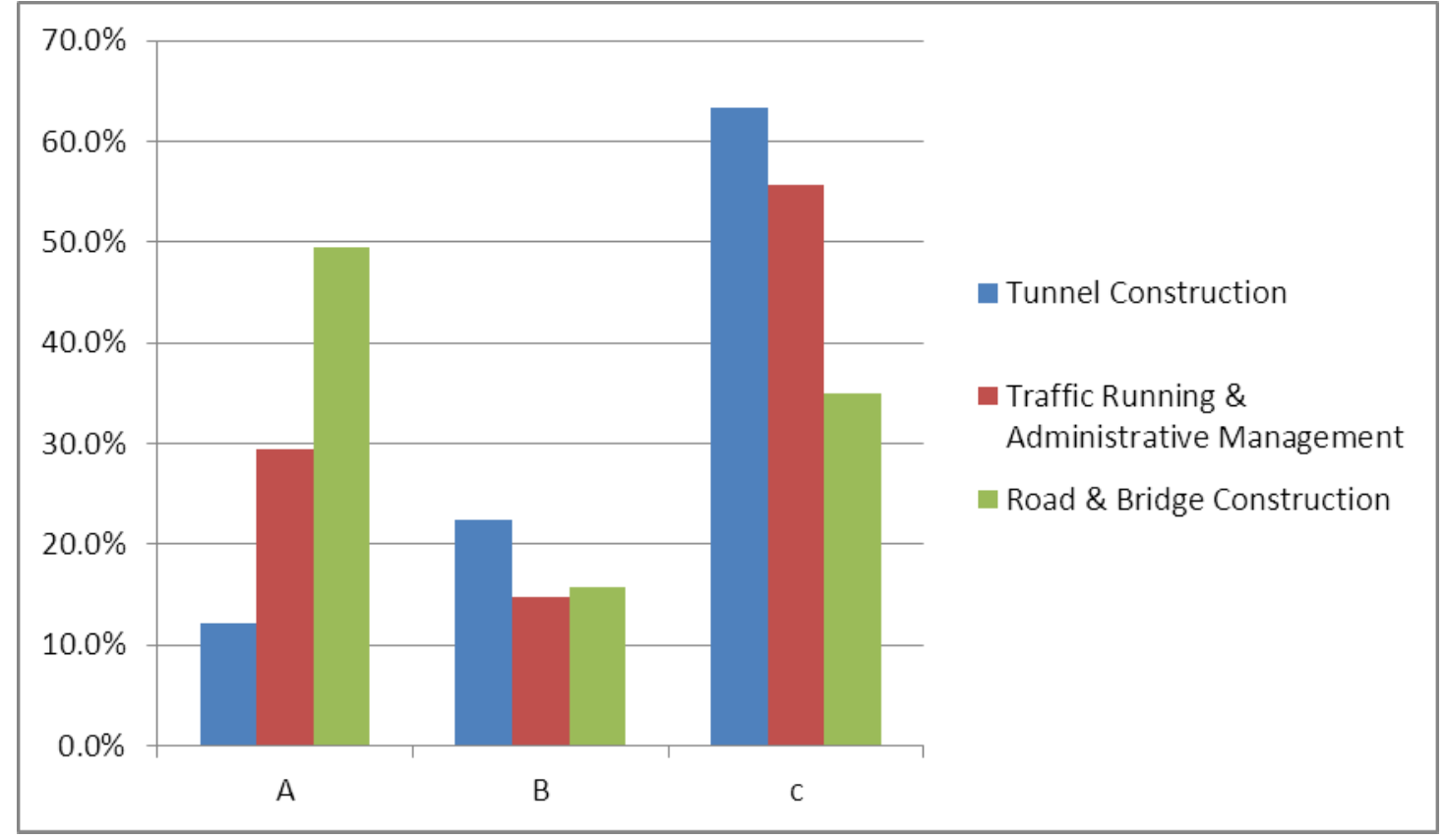

q20

\section{A. English Linguistic Knowledge \\ B. Subject Matters \\ C. Both}

Figure 4. Final Academic Test's Focus in BCEE CBI Course

However, in Figure 4, we can find that there were significant differences among 3 major students in how to assess academic grade in the final course test. Only about $10 \%$ of students 
in Tunnel Construction Major showed preferences in English linguistic Knowledge test, while $70 \%$ in this major preferred to test both English Linguistic and Subject Content Knowledge. By contrast, students in Road \& Bridge Construction Major demonstrated great confidence in English linguistic Knowledge test (at 50\%) and only 30\% of them wanted to have an integrative English Language-and-Subject Content test in the final examination. In Traffic Running \& Administrative Management Major, students exhibited an equal inclination to have both Language-and-Content as final test (50\%) and other 2 individual aspects combined (50\%). In conclusion, the major with better English foundations preferred English linguistic Knowledge as the means of final test in this course; whilst the major with more bountiful Building \& Construction Knowledge supported to test both their English linguistic skills and Subject Content Knowledge as a comprehensive final course evaluation.

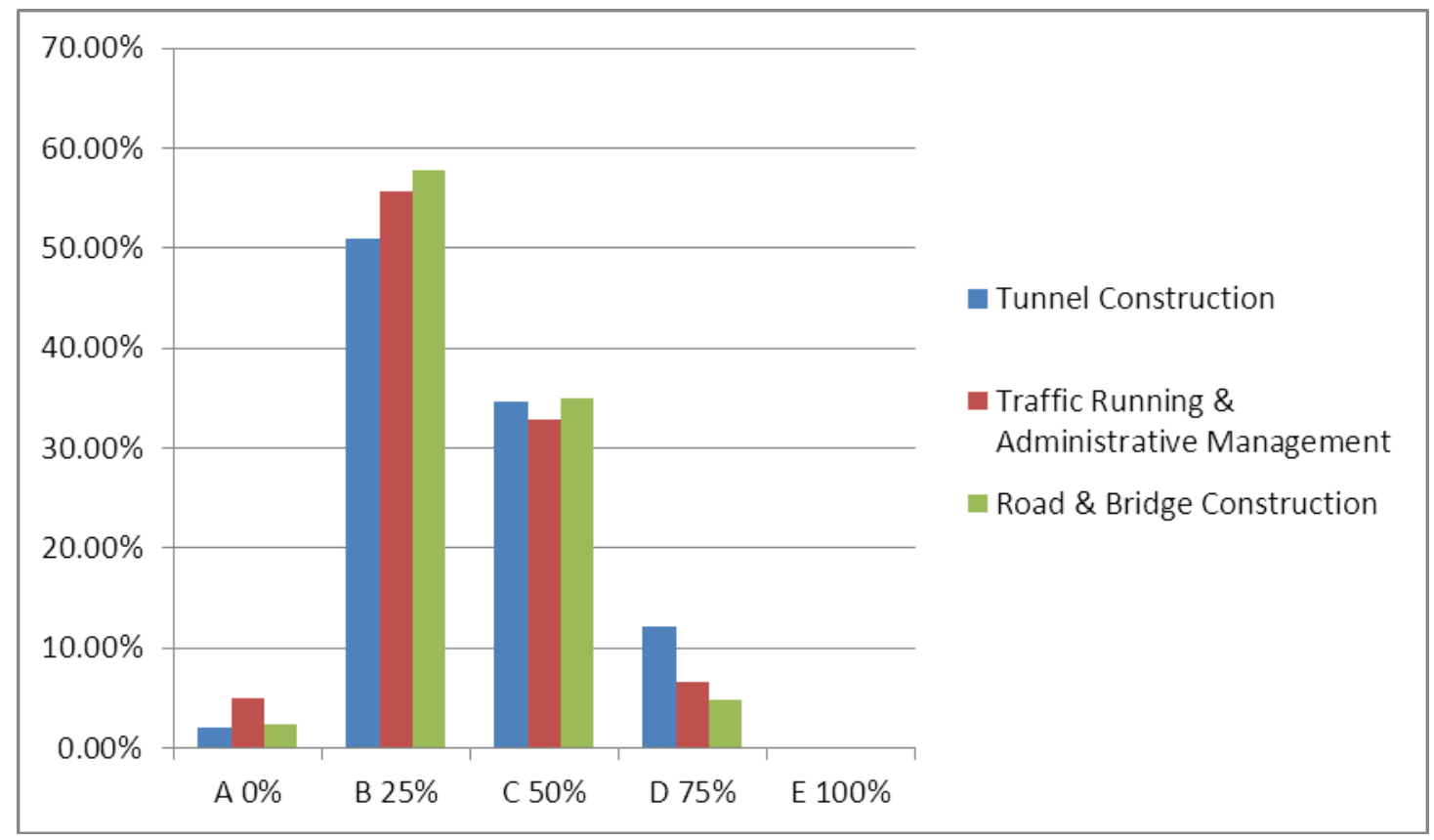

q13

Figure 5. Percentage of Knowledge Students Can Understand in BCEE

From the pie charts in Figure 5, we can find that over half of the students can understand $100 \%$ of instructed knowledge in BCEE class in all 3 majors; over $1 / 3$ of students can understand $75 \%$; less than $10 \%$ of students combined understood only a little $(25 \%)$ or nothing at all $(0 \%)$ in the class. What needs our attention is that in Road \& Bridge Construction Major, $57.83 \%$ of students understood $100 \%$ of knowledge in the class (the highest among 3 majors) and only $7.23 \%$ hardly understood the subject content and English language in the class (the lowest among 3 majors). This statistical number complied with the researcher's teaching observation that among all of 3 majors, Road \& Bridge Construction Major students had the most solid English foundations and profound Building \& Construction Engineering professional knowledge which can be manifested by their critical thinking and actively answering teacher's questions in Building \& Construction field, giving 


\section{Macrothink}

responses and speaking in English in front of classmates etc. Particularly for a couple of top students, they can even explain and elaborate on some complicated specialty subject content knowledge in English to the teacher, this phenomenon was not found in other 2 majors.

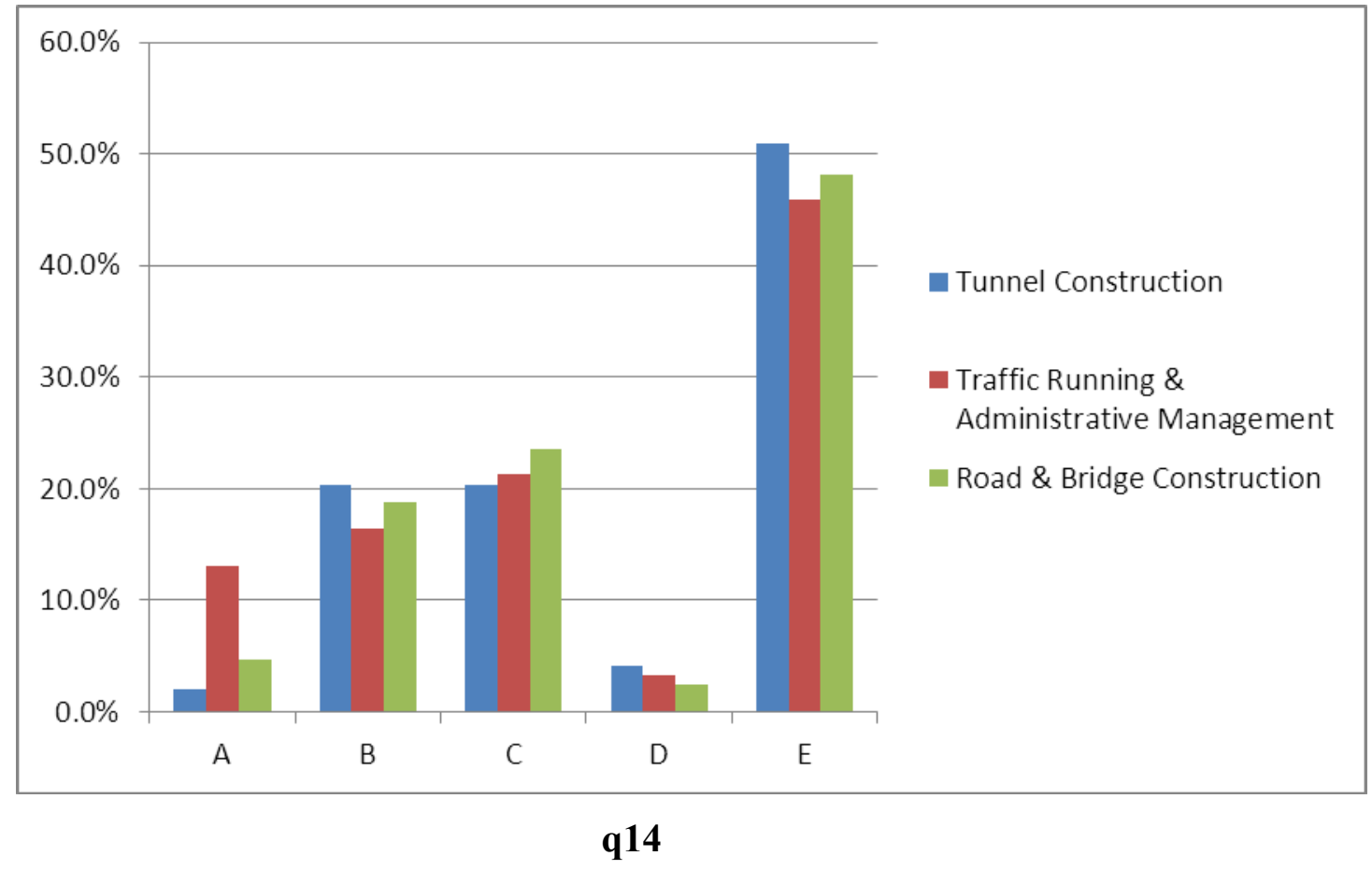
A. Grammar
B. Words \& Phrases
C. Oral English Practice
D. Writing Skills
E. Subject Matters

Figure 6. Percentage of Knowledge \& Skills Students Prefer to Learn

In Figure 6, we can further get a clearer picture of what sort of knowledge and skills students really want to learn the most in BCEE CBI classes. The bar chart showed that the majority of students preferred to learn subject matters in BCEE course (a dominant over 50\%) rather than English Grammar (accounting for less than 10\%). In addition, about 20\% of students in each major showed interest and demands in learning English Words \& Phrases and practicing Spoken English proficiency respectively. However, writing skills, the least favored in all 5 categories made up only less than 5\% in general. The data indicates that most of sophomore undergraduates had strong interest and were highly motivated to pursue their major-related subject content knowledge, i.e. Building \& Construction Engineering knowledge along with improving their English linguistic skills in vocabulary and oral ability. Nonetheless, the fact that only a few students favored in learning English grammar or English writing skills wasn't out of expectation. These 2 aspects are always the least like-to-learn English linguistic categories for learners' with poorer English basic knowledge and skills. 


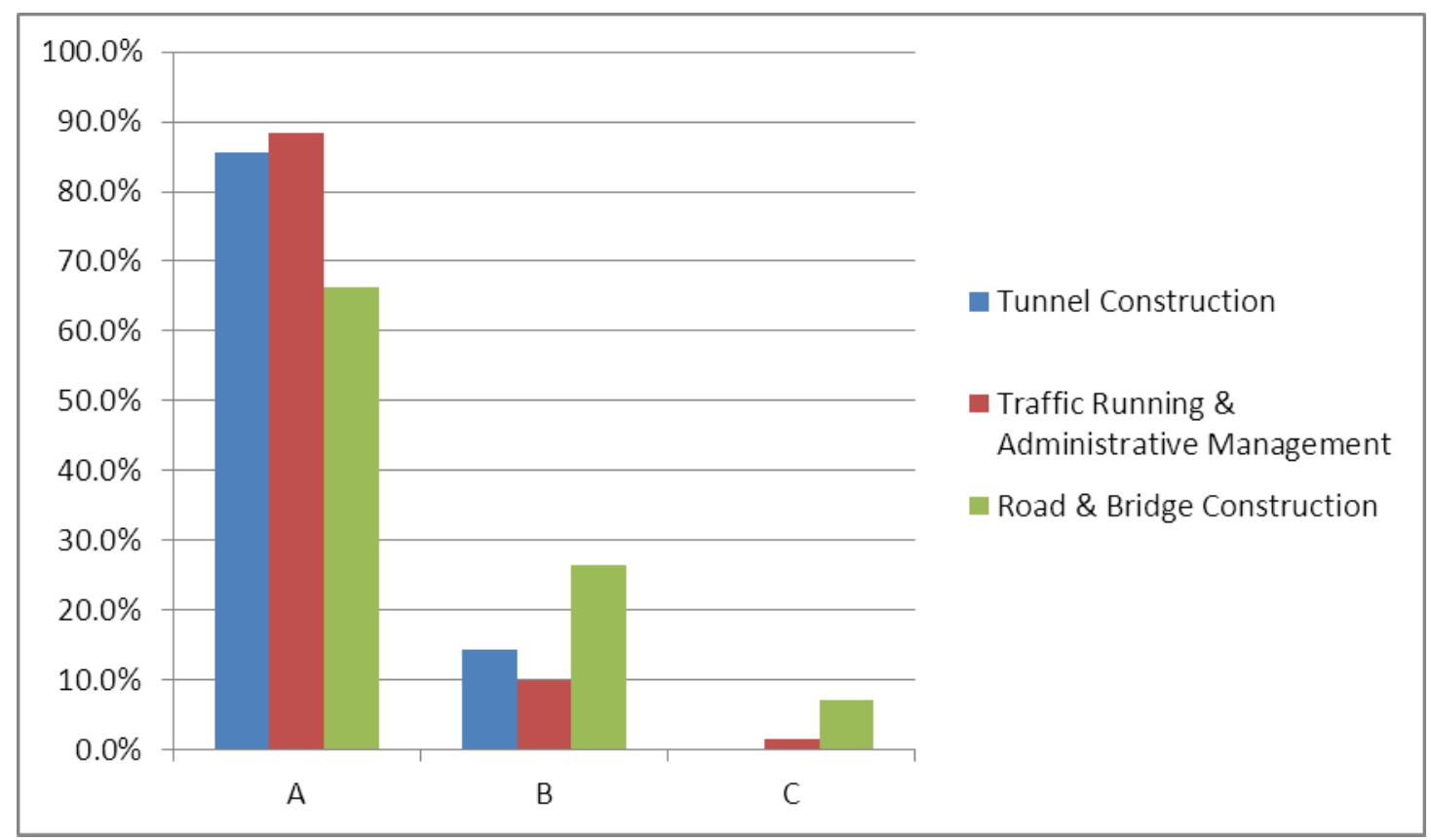

q17

\section{A: Agree}

B: I don't know

C: Disagree

Figure 7. Students' Judgment of English Teacher's Competence of Teaching BCEE CBI Course

By comparison with Figure 1, Figure 7 showed students' judgment of English teacher's competence of instructing BCEE CBI course. In this bar chart, it is conspicuous that the large majority of students (at a dominant $70 \%$ to $90 \%$ in respective) in 3 majors acknowledged that their English teacher was very competent to instruct BCEE CBI course in which both subject matters and English language were involved. Nevertheless, still only a few students (less than 5\%) in Traffic Running \& Administrative Management Major and Road \& Bridge Construction Major considered their English teacher was not adequately qualified to teach this course. The explanation for this maybe that in teaching BCEE CBI course in these 2 majors whose English foundations and subject knowledge appeared better than those in Tunnel Construction Major, in order to stimulate their creative thinking and to the largest extent excavate their learning potential, the teacher chose to ask much more profound specialty questions in regard to professional building and construction industry which he seemed not to be assured of.

\section{Main Findings of the Study}

Based on qualitative Interview with both Chinese and Foreign English teachers and both male and female students in 3 majors in the vocational and technical college in Sichuan Province, along with quantitative Questionnaire Survey to students, plus researcher's classroom observation and communication with students outside of the class, major findings regarding 4 main research questions were listed as follows.

\subsection{Findings Related to Research Question 1}

In general, vocational and technical college students in the research gave supports to CBI in 
their College English course. On the one hand, they wanted to use CBI method to improve their comprehensive English skills; on the other hand, they wish to learn some practical subject matters related to their major which could meet their learning needs and build a higher and better platform for their future career. However, due to poor English linguistic foundations and a lack of subject professional knowledge, a great number of students in all majors found it difficult to learn CBI course, especially when English was the classroom instruction language. In addition, students with higher English level preferred to acquire more content knowledge in this course to broaden their horizons and enrich their subject experiences; while students with lower English level favored in obtaining more English linguistic knowledge to change their actual poor English learning situation, particularly they are in a great demand to use English as a communication tool in real-life living and working contexts and achieve high scores in final English examination and CET3, 4 and 6.

\subsection{Findings Related to Research Question 2}

From the perspective of students, CBI can not only motivate them to learn English with a considerable increase in learning motives and interest, but also it can stimulate students' critical thinking, willingness to practice spoken English in class and act as a catalyst to incorporate English language learning with major-related contents acquisition in which required English course was closely linked with practical application of major knowledge for students' future occupation. In the opinion of teachers at home and abroad in the vocational and technical college in Sichuan Province, first of all, owing to CBI's clearer orientation and closer relevance to students' learning subject, their learning motivation and attitudes were significantly accelerated as they can apply what they learned in BCEE CBI course into practical living and working use. Secondly, CBI provided a better working platform and stage for students in their future career where English would be used as a necessary communicative tool to exchange ideas, make negotiations and cooperate with foreign colleagues. Last but not least, $\mathrm{CBI}$ is an ideal balance between English language learning and subject content knowledge acquisition which can offer more opportunities for students to further their specialty major study oversea and earn more money if they can live and work abroad with higher English proficiency.

\subsection{Findings Related to Research Question 3}

On students' side, the most obvious issue was their lack of English foundations which resulted in their tiring, tedious and strenuous learning specialty English vocabulary and terminology within the subject. Aside from it, how much English linguistic knowledge and how many subject content matters should be distributed in CBI classes was still in disagreement: students with better English basics preferred to learn more major-related content knowledge in the class whereas those with poorer foundations wanted to learn more English linguistic knowledge and keep CBI course language-orientated in essence. In the meanwhile, teachers in the vocational and technical college in Sichuan Province found it very difficult and impractical to use English solely in the classroom to instruct CBI classes for students' general poor understanding of subject matters instructed in English language. What's worse, sophomore students in the vocational and technical college in Sichuan Province were not stratified as "A, B, C" classes as they did in freshman year which made it very difficult for teachers to make appropriate teaching plans and suitable teaching designs 
that can cater to every students' needs in the same class. In addition, it was also a remarkable challenge for English teachers to impart subject content knowledge which they were not familiar with or even didn't get contact with before.

\subsection{Findings Related to Research Question 4}

In a word, all of the students and teachers agreed that teachers must have solid English linguistic skills and indispensible educational knowledge. What's more, sound preparation for professional subject terminology and basic concepts in related CBI course was inevitable. If it is possible and convenient, pre-service working and training experiences in content-relevant industrial companies should be provided for English teachers to deepen their acquaintance, understanding and mastery of subject content knowledge and skills, making them better competent and qualified for CBI course as a consequence.

\section{Implications of the Study}

Content-based English Instruction in Chinese vocational and technical college context combines learning of English language and subject content matters together which complies with experiential teaching method where students can acquire the target language when they are learning subject knowledge and finishing learning tasks.

Theoretically speaking, CBI provides an ideal structure for language learning in which the focus of study is subject matters rather than the target language itself. When students are paying their attention to meaning, this top-down studying method is beneficial for students to acquire English language and construct English linguistic knowledge structure through pursuing content knowledge related to their major subject. Moreover, cooperative learning practices in CBI promote interactive spoken English intercourse among students which can therefore improve students' English communicative competence in the process of using English to solve problems in real-life communication. In CBI learning environment, teachers and students with higher learning abilities can build up "Scaffolding" for students with poorer learning abilities, helping them to reach ZPD (Zone Of Proximal Development) and realizing their individual learning objectives, i.e. to enrich subject content knowledge level while increasing English linguistic proficiency.

In terms of real practical effects of CBI in vocational and technical college context, CBI can facilitate students' learning. First and foremost, in CBI model, students are accessible to large amounts of authentic language input which may simulate English acquisition in a natural native English-speaking environment. Secondly, learning activities with genuine meanings can stimulate students' strong motivation to learn both subject matters and English language which can be used in practical communication and problem-solving process. Thirdly, in CBI classes, students are no longer passive knowledge "Receiver" as those in traditional teacher-dominated classes. On the contrary, they positively take over learning tasks and construct their own understanding of knowledge in a student-centered learning environment. Last but not least, CBI supplies students with adequate and bountiful opportunities to practice various linguistic skills while improving their integrated English level. In a word, CBI has so many benefits and advantages for students to consolidate English foundations while enriching subject content knowledge in their major in Chinese vocational and technical college context and it is worthwhile to be tried and carried out comprehensively and extensively to keep 
abreast with $21^{\text {st }}$ Century Chinese College English Reform.

\section{Suggestions for Future Research}

In order to meet the challenges and solve existing problems of CBI BCEE course in the vocational and technical college in Sichuan Province, a number of suggestions were proposed by the author as following.

1). Cultivate "Double-qualified" teachers

In light of the dilemma that English teachers don't know subject specialty knowledge while subject teachers don't have competence in basic English skills, to foster "Double-qualified" teachers who have both sufficient subject content knowledge and English linguistic proficiency is in extreme urgency. This trend also complies with the characteristics and constructional keys in Chinese vocational and technical colleges with has been strongly advocated by the mass public and put on agenda by Chinese Higher Education Central Department.

2). Seek help and assistance from subject experts

After this study in the vocational and technical college in Sichuan Province, a typical vocational and technical college in China, the author found out the biggest problem for English teachers to widely accept, strongly support and efficiently implement CBI in their classes was that they were left high and dry to assume the accountability of instructing CBI courses alone, without necessary and indispensible help and assistance from subject teachers or experts. This critical issue is prevalent in Chinese colleges and universities and nearly all of other Chinese vocational and technical colleges are without exceptions.

To remove this hindrance in front of CBI, on the one hand, subject teachers with competent English proficiency should share the responsibilities of promoting CBI courses as regards their own specialty major, cooperating and negotiating with English teachers together to pursue the most suitable teaching model in CBI classes and strive to construct CBI programs which are novel and advantageous to students' course study and future lifelong career. On the other hand, it is imperative for college leaders' panel to take some effective measures to alleviate English teachers' excessive burdens on CBI by means of inviting authoritative subject experts outside to give eye-opening lectures and intensive subject-related training courses to enrich English teachers' subject specialty skills and complement their deficiency in content knowledge as well. In the meanwhile, college could contact companies in relevant subject industries and take advantages of vacation time to send English teachers to do on-site translation jobs or work as internship with salaries so as for them to get familiar with the subject in practical working context and deepen their understandings and mastery of the terminology, jargons, basic knowledge and skills in content subject.

3). Develop authentic textbook

According to Stryker and Leaver (1997), authentic language and textbook should be advocated in CBI courses for language input is of crucial significance in students' SLA. Accordingly, research on and development of textbook should be put into serious consideration among teachers and experts. The design and development of textbook CBI used must consider a variety of important issues, such as content and task authenticity, students' real needs, interest, cognitive abilities, English linguistic difficulty, convenience of textbook's 
supply, supplementary teaching material and use of modern technology in teaching including MOOCs, Flipped Classes, Micro-classes so on and so forth. In addition, appropriate textbook evaluation system should be created to guarantee the textbook's effectiveness and efficiency in facilitating students' learning both English language and subject content knowledge in CBI courses. To cater to distinctive needs and understanding abilities of students in Chinese vocational and technical colleges, it is plausible to import western authentic textbooks with proper and suitable adjustment and adaptation to Chinese learners whose communicative competence in real-life living and working conditions should be highly emphasized and highlighted.

\section{Conclusion}

During half a year's strenuous study of the application of CBI model in a vocational and technical college in Sichuan Province, the author obtained invaluable first-hand research information and data as a first-line CBI teacher and research participant. Through scientific qualitative and quantitative methods and via real experiences in instructing CBI courses, after investigating $\mathrm{CBI}$ model in this college the author hence proclaims that $\mathrm{CBI}$ is a highly-efficient, widely-applicable, interest-motivating English teaching method in Chinese vocational and technical colleges. Although CBI's applicability and effectiveness have been widely explored by researchers in China and across the world, its feasibility in different kinds of Chinese vocational and technical colleges and the most suitable instruction model in different EFL/ESL contexts are still under investigation. All in all, the author believes that $\mathrm{CBI}$ is the epoch-making English teaching method in $21^{\text {st }}$ century and proves to be applicable and feasible in various English learning backgrounds from different parts of the world. Beyond doubt, it is destined to pave the way for Chinese College English Reform and equip both Chinese and international college students with "double-qualifications" i.e. English linguistic competence and major-related professional skills which are essential in their real-life working contexts. With these qualifications, college graduates will become much more competent and qualified for incoming international competitions, fiercer challenges and greater opportunities in the global labor market and exert more crucial impacts on the economic growth in the new era.

\section{Acknowledgement}

Fund: Funding Project of Sichuan Nursing Vocational College in 2017 (20172RY10).

\section{References}

Brinton, D. M., Snow, M. A., \& Wesche, M. B (1989). Content-based second language instruction. New York: Newbury House.

Brinton, D. M. (1997) . The challenges of administering content-based programs. In M. A. Snow, \& D. M. Brinton (Eds.). The Content-based classroom: Perspectives on integrating language and content (pp. 340-346). New York: Longman.

Burger, S., \& Chretien, M. (2001). The development of oral production in content-based second language courses at the University of Ottawa. The Canadian Modern Language Review, 1, 84-102. https://doi.org/10.3138/cmlr.58.1.84

Chang, J. Y. (2015). A study of CBI reform for English majors in the lower division in the Chinese context. Beijing: Peking University Press. 
Chapple, L., \& Curtis, A. (2000). Content-based instruction in Hong Kong: Student responses to film. System, 28, 419-433. https://doi.org/10.1016/S0346-251X(00)00021-X

Chen, T. Y. (1998). ESP in technology colleges: instruction and investigation. In The Proceedings of the Seventh International Symposium on English Teaching (pp. 279-288). Taipei: The Crane Publishing Co., Ltd.

Chumpavan, S. (2001). A comparative study of two English as a foreign language (EFL) programs: Non-content-based and content-based at the university level in Thailand. Unpublished doctoral dissertation, Illinois State University.

Crandall, J. (1987). ESL through content-area instruction: Mathematics, science, and social studies. Englewood Cliffs, NJ: Prentice Hall.

Dupuy, B. C. (2000). Content-based instruction: Can it help ease the transition from beginning to advanced foreign language classes? Foreign Language Annals, 33, 205-222. https://doi.org/10.1111/j.1944-9720.2000.tb00913.x

Edwards, H. P., Wesche, M. B., Krashen, S., Clement, R., \& Kruidenier, B. (1984). Second language acquisition through subject matter learning: A study of sheltered psychology classes at the University of Ottawa. Canadian Modern Language Review, 41, 268-282.

Grabe, W., \& Stoller, F. L. Content-based instruction: Research foundations. (1997). In M. A. Snow \& D. H. Brinton (Eds.). The content-based classroom: Perspectives on integrating language and content (pp. 5-21). White Plains, NY: Longman.

Gu, Y. Q., \& D, L. Z. (2005). Lessons from Hong Kong's experiment with English-medium instruction. Modern Foreign Languages, 2, 43-52.

Holten, C. (1997). Literature: A quintessential content In M. A. Snow, \& D. M. Brinton (Eds.). The Content-based classroom: Perspectives on integrating language and content (pp. 377-387). White Plains, NY: Addison Wesley Longman.

Huang, Y. K. (2003). Easing into e-news: An EAP course for advanced readers. In Selected Papers from the Twelfth International Symposium on English Teaching (pp. 414-423). Taipei: Crane Publishing Co.

Hsu, H. L. (2000). Teaching technical English in a two-year college. In Selected Papers from the Ninth International Symposium on English Teaching (pp. 628-639). Taipei: Crane Publishing Co., Ltd.

Jan, L. (2004). Content-based university EAP in Taiwan: A course integrating CALL and TBLT. Unpublished master's thesis, California State University.

Kasper, L. F. (1994). Improved reading performance for ESL students through academic course pairing. Journal of Reading, 37, 376-384.

Kasper, L. F. (2000). Content-based college ESL instruction. Mahwah, NJ: Erlbaum.

Liu, F. X., \& Cai, Y. (1997). Implementation of an immersion language course in a Chinese context: an experimental study. Modern Foreign Languages, 3, 44-51.

Met, M. (1999). Making Connections. Foreign Language Standards: Linking Research, Theories, and Practices. Lincolnwood, IL: National Textbook Co.

Mohan, B. (1986). Language and content. Reading: Addison-Wesley Publishing Company.

Richards, J., \& Rodgers, T. (2001). Approaches and methods in language teaching. 


\section{IIMacrothink

Cambridge: Cambridge University Press. https://doi.org/10.1017/CBO9780511667305

Srole, C. (1997). Pedagogical responses from content faculty: Teaching content and language in History. In M. A. Snow, \& D. M. Brinton (Eds.). The Content-based classroom: Perspectives on integrating language and content (pp. 104-116). White Plains, NY: Longman.

Stryker, S. B., \& Leaver, B. L. (1997). Content-based instruction in foreign language education: Models and methods. Washington, DC: Georgetown University Press.

Torres, C. I. (2000). The bilingual immersion model compared to the traditional model for teaching English in Puerto Rico. Unpublished doctoral dissertation, Dowling College.

Wesche, M. B., \& Skehan, P. (2000). Communicative, task-based, and content-based language instruction. In R. B. Kaplan (Ed.). The Oxford handbook of applied linguistics (pp. 207-243). NY: Oxford University Press.

Xing, L. (2006). An experimental study of content-based instruction in extensive reading. Unpublished master's thesis, Beijing Normal University.

$\mathrm{Xu}, \mathrm{D}$. K. (2006). A CBI experimental report on western linguistic courses in Chinese language major. Foreign Language Teaching Abroad, 1, 29-33.

Yuan, P. H. (2014). A study on CBI in the Chinese college English context. Beijing: Social Sciences Academic Press.

Zhu, P. (2003). A comment on bilingual education experiments in Shanghai's secondary and primary schools. Curriculum, Teaching Material and Method, 6, 52-58.

\section{Copyright Disclaimer}

Copyright reserved by the author(s).

This article is an open-access article distributed under the terms and conditions of the Creative Commons Attribution license (http://creativecommons.org/licenses/by/3.0/). 